\title{
ANALISIS SOSIO YURIDIS TERHADAP PERNIKAHAN USIA DINI DAN PERCERAIAN DI JAWA TIMUR
}

\author{
Sukamto \\ Universitas Islam Negeri Sunan Ampel I Jl. Jend. A. Yani I I 7 Surabaya \\ kamtoindoraya@yahoo.com
}

\begin{abstract}
This study examines the dynamics of early marriage and divorce occurring in a strong Islamic cultural tradition. The results of the research show that there are significant factors on the early marriage and divorce rates as the influence of socio-cultural traditions of the societies. These symptoms can not be separated from the influence of social systems and values prevailing in society. Local cultural traditions that only take place in certain areas are often used as a foothold in early marriage as well as the prevailing social systems. Although both of the local cultural traditions and social systems have a significant role in influencing the cases, but in terms of nature, marriage and divorce are more individual and casuistic issues. It is found that in addition to these two factors, economic factor also become the main variable in motivating people to do early marriage and divorce .
\end{abstract}

Keywords: Early marriage, divorce, and socio-juridical factors

Abstrak: Studi ini mengkaji tentang dinamika pernikahan usia dini dan perceraian yang terjadi di wilayah Jawa Timur berbasis tradisi budaya Islam yang kuat. Hasil penelitian menunjukkan bahwa terdapat faktorfaktor yang cukup signifikan terhadap timbulnya gejala pernikahan usia dini serta meningkatnya angka perceraian, yakni pengaruh tradisi sosial budaya masyarakat. Gejala tersebut tidak dapat dilepaskan dari pengaruh sistem dan nilai-nilai sosial yang berlaku di masyarakat. Tradisi budaya lokal yang hanya berlangsung di daerah tertentu sering dijadikan sebagai pijakan dalam pernikahan usia dini, begitu juga dengan sistem sosial yang berlaku di wilayah tersebut memberikan pengaruh terhadap meningkatnya angka perceraian. Meskipun tradisi budaya lokal dan sistem sosial mempunyai peran dalam mempengaruhi peristiwa tersebut, tetapi dari segi sifatnya, pernikahan dan perceraian lebih individual dan persoalan kasusistik, maka ditemukan bahwa selain kedua faktor tersebut, faktor ekonomi menjadi variabel utama dalam 
menggerakan seseorang melakukan pernikahan usia dini dan perceraian.

Kata Kunci: Pernikahan usia dini, perceraian, dan sosio yuridis

\section{Pendahuluan}

Pernikahan merupakan awal dari sebuah keluarga kecil yang menjadi inti dari hidup bermasyarakat. Cikal bakal kehidupan dalam suatu komunitas tidak lain bersumber dari adanya kehidupan-kehidupan yang berhimpun dalam keluarga-keluarga yang disebut dengan kehidupan rumah tangga, yaitu yang hanya terdiri dari pasangan suami, istri dan anak keturunannya. Dari arah kehidupan yang demikian ini, akan terbentuk kehidupan yang lebih luas yang dinamakan kehidupan masyarakat. Ikatan pernikahan sebagai dasar kehidupan, diharapkan dapat menimbulkan suatu kehidupan masyarakat yang teratur dan berada dalam suasana damai.

Melaksanakan pernikahan dengan mengikuti ketentuanketentuan yang telah diatur dalam al-Qur'an dan Hadist merupakan salah satu ibadah bagi orang Islam. ${ }^{1}$ Yakni ibadah yang mengkombinasikan antara hubungan yang bersifat horisontal dan hubungan yang bersifat vertikal. Tujuan hubungan yang horisontal adalah dapat meramaikan kehidupan dunia yang tenteram dan damai. Semakin pesatnya populasi umat manusia sebagai dampak hubungan yang demikian adalah sesuatu yang menjadi kebutuhan dasar manusia itu sendiri. Sedangkan hubungan bersifat vertikal memiliki arti bahwa pernikahan itu bukan semata-mata tuntutan akan kebutuhan manusia, seperti kebutuhan biologis, melainkan merupakan suatu perintah agama yang mempunyai nilai ibadah.

Dalam perjalanannya, tidak semua pernikahan dapat berjalan mulus. Tatkala semua harapan dan kasih sayang yang ada dalam pernikahan telah musnah, dan pernikahan menjadi sesuatu yang

I Soemiyati, Hukum Perkawinan Islam dan Undang-undang Perkawinan (Undang-Undang No.I, Tahun 1974, Tentang Perkawinan), (Yogyakarta: Liberty, 1982), 4. 
membahayakan bagi pasangan itu sendiri dalam rumah tangganya, dan untuk kepentingan bersama, mereka tidak dapat disatukan dalam kehidupan mereka, maka perpisahan di antara mereka boleh dilakukan.

Islam memang berusaha menguatkan ikatan pernikahan. Namun berbeda dengan ajaran agama lain, Islam tidak mengajarkan bahwa pasangan dalam pernikahan tidak dapat dipisahkan lagi. Bila pasangan tersebut telah benar-benar rusak dan apabila dipertahankan sebaliknya akan menimbulkan penderitaan berkepanjangan bagi kedua belah pihak dan akan melampaui ketentuan-ketentuan Allah, maka ikatan itu harus dikorbankan. Pengorbanan tersebut mempunyai tujuan agar kedua belah pihak tidak hidup dalam kondisi dan suasana kekacauan rumah tangga yang membuka peluang tindak kekerasan.

Dengan mempelajari suasana rumah tangga yang demikian rapuh, disertai dengan tekanan batin atau aspek psikologis pasangan suami istri, maka dalam menyelesaikan persoalan itu berarti pintu perceraian harus dibuka. ${ }^{2}$ Peluang bercerai pasangan suami istri terbuka semata-mata sebagai solusi yang terbaik dalam menyelesaikan kebuntuan yang menimbulkan ketidakharmonisan dalam rumah tangga. Meskipun pintu perceraian dibuka, tidak berarti tanpa suatu sebab perceraian dapat dilakukan. Perceraian baru diperbolehkan apabila kerukunan dalam rumah tangga tidak dapat disatukan kembali dan pasangan suami istri saling bersikukuh untuk tidak dapat hidup bersama dalam rumah tangga. Dengan demikian, peristiwa perceraian mengakhiri suatu ikatan pernikahan yang selama ini dibangun oleh kedua mempelai. Sejak saat itu, kedua pasangan yang hidup dalam sebuah keluarga tak ingin melanjutkan kehidupan pernikahannya dalam kehidupan bersama.

${ }^{2}$ Rahmat Hakim, Hukum Perkawinan Islam, (Bandung: Pustaka Setia, 2000), 145. 
Peristiwa perceraian merupakan tahap akhir dari suatu pernikahan. Ketika suatu rumah tangga yang diikat dalam suatu pernikahan, kemudian pasangan suami-istri sering diwarnai dengan pertengkaran, merasa tidak bahagia, ketidaksetiaan pasangan, atau masalah lainnya yang berujung dengan timbulnya ketidakharmonisan pasangan itu, maka seringkali terpikir oleh pasangan suami istri tersebut untuk segera mengakhiri pernikahan. Dengan berbagai pertimbangan yang sangat mendasar, bercerai dengan pasangan dianggap sebagai solusi terbaik bagi banyak pasangan yang menikah, setelah semua cara untuk berdamai tidak menemukan titik temu. Alasan lain yang umumnya dijadikan gunjingan masyarakat adalah bercerai merupakan pembelajaran yang berharga bagi pasangan hidup dan sebagai jalan keluar yang baik untuk mengakhiri rasa sakit hati dari pasangan suami istri.

Dalam pasal 38 Undang-Undang Perkawinan menyebutkan bahwa ikatan perkawinan dapat putus karena beberapa alasan, diantaranya adalah: pertama, karena peristiwa kematian, kedua karena diakibatkan oleh perceraian dan ketiga, adalah atas keputusan pengadilan. Dengan mengacu pada norma-norma dalam UU No. 1 tahun 1974, maka sesungguhnya jalan yang terbaik untuk mengakhiri ikatan perkawinan adalah dengan cara melakukan perceraian. Dalam aturan tersebut mengandung pengertian bahwa permulaan seseorang bertemu dalam ikatan keluarga didasarkan pada ikatan yang sah menurut hukum, yaitu dengan ikatan pernikahan, maka ketika pasangan itu ingin berpisah satu dengan lainnya, dapat mengakhirinya dengan cara bercerai. Jadi, perceraian adalah langkah terakhir untuk memutus ikatan pernikahan yang telah dilakukan, sedangkan pernikahan adalah langkah awal yang mempertemukan seseorang dengan orang lain dalam kehidupan rumah tangga.

Sedangkan dalam Undang-Undang Perkawinan mempunyai prinsip bahwa setiap pasangan yang telah melakukan ikatan pernikahan dan hidup dalam sebuah keluarga, pasangan tersebut 
harus hidup dalam suasana harmonis dan penuh kasih sayang antara suami istri. Jika dalam perjalanan menggapai hidup berumah tangga terjadi persoalan antara suami-istri, maka keduanya berupaya untuk mencari solusi penyelesaian terhadap persoalan itu, sehingga keutuhan kehidupan keluarga dapat dipertahankan. Dengan demikian, pasangan suami-istri berupaya menghindar dari perceraian, bahkan dalam pasal 39 ayat (1) menyimpan makna yaitu tidak mudah bagi pasangan untuk melakukan perceraian, sebagaimana dalam pasal dan ayat itu disebutkan bahwa perceraian hanya dapat dilakukan di depan sidang pengadilan yang berwenang setelah pengadilan yang bersangkutan berusaha dan tidak berhasil mendamaikan kedua belah pihak yang berkeinginan untuk memisahkan diri dengan pasangannya.

Di Jawa Timur, angka perceraian meningkat setiap tahunnya yang semuanya memiliki ragam faktor penyebab dengan dampak sosial yang juga bervariasi. Pada 2011, angka perceraian di Jawa Timur tercatat mencapai 25.907 kasus, kemudian meningkat di tahun 2012 mencapai 27.425 kasus. Pada 2013 menjadi 74.777 kasus dan pada 2014 meningkat lagi menjadi 81.672 kasus perceraian dan tahun 2015 diperkirakan mencapai 100 ribu kasus. ${ }^{3}$ Angka perceraian yang tidak pernah menurun, malah meningkat membuat pemerintahan provinsi Jawa Timur merasa prihatin dan karenanya langkah yang ditempuh adalah meningkatkan konsolidasi dengan instansi terkait, terutama dengan Kementerian Agama di tingkat Provinsi dan tingkat kabupaten/kota sampai ke tingkat rendah, yaitu KUA-KUA sebagai instansi yang bersinggungan langsung dengan masyarakat.

Meningkatnya angka perceraian di Jawa Timur kini menjadi sorotan BKKBN (Badan Kependudukan dan Keluarga Berencana Nasional) Jawa Timur, mengingat hasil survei BKKBN

${ }^{3}$ Tekan Angka Perceraian, Kemenag Jatim Setuju Wacana Kursus Pra Nikah, http://Jatimprov.Go.Id/Read/Berita-Pengumuman/Tekan-Angka-Perceraian-Kemenag-JatimSetuju-Wacana-Kursus-Pra-Nikah, diakses tanggal I5 Agustus 2017. 
menunjukkan kegagalan berumah tangga didominasi akibat pernikahan di usia yang belum matang atau pernikahan usia dini. Jumlah pasangan suami istri yang memilih jalan perceraian makin meningkat tajam dibandingkan tahun-tahun sebelumnya. Pemicu pisah ranjang pasangan suami istri tersebut mayoritas didominasi oleh pasangan dari penikahan usia dini atau menikah dalam usia anak-anak. Dari data di Pengadilan Agama, rata-rata perceraian tersebut disebabkan oleh ketidakmampuan pasangan usia dini dalam memenuhi kebutuhan hidup rumah tangganya atau faktor ekonomi.

Menurut kepala BKKBN Provinsi Jawa Timur, Dwi Listyawardani, dari jumlah total hampir 5.000.000 jiwa penduduk di Jawa Timur, terdapat 500.000 pernikahan setiap tahun dengan angka perceraian mencapai 80.000 pasangan. Faktor tertinggi dari kegagalan berumah tangga dan angka perceraian adalah karena pernikahan dini. Usia 16 tahun sebagai batas minimal wanita menikah yang tercantum dalam Undang-Undang Perkawinan dinilai BKKBN sebagai usia yang terlalu muda bagi wanita untuk menikah. ${ }^{4}$ Adapun data penelitian Pusat Kajian Gender dan Seksualitas Universitas Indonesia tahun 2015, menunjukkan angka perkawinan dini di Indonesia berada pada peringkat kedua teratas di kawasan Asia Tenggara. Terdapat sekitar 2 juta dari 7,3 perempuan Indonesia berusia di bawah 15 tahun yang sudah menikah dan putus sekolah. Jumlah itu diperkirakan naik menjadi 3 juta orang pada tahun $2030 .^{5}$

Dari paparan tersebut di atas, maka penulis memandang perlu mengkaji tentang dinamika pernikahan usia dini dan perceraian yang terjadi di wilayah-wilayah Jawa Timur yang memiliki angka pernikahan dan perceraian tinggi dan cenderung selalu naik dari tahun ke tahun. Daerah yang memiliki kesatuan

4 Nur Ulfainyy D, Angka Perceraian di Jawa Timur Capai 80.000 Per Tahun http://surabayanews.co.id/20 I 5/08/2 I/33 | | 4/angka-perceraian-di-jawa-timur-capai-80-000-pertahun.html, diakses I 5 Agustus 2017.

${ }^{5}$ lbid. 
sosial geografis yang luas, saling berkaitan, dan berkesinambungan, sehingga diasumsikan bahwa kesatuan sosial di wilayah ini memiliki kemiripan karakteristik atau kecenderungan. Daerah yang menyimpan kekuatan tradisi sosial budaya yang hampir sama, sebagai daerah berbasis religius, yang ditandai kuatnya tradisi keagamaan, dengan tingkat ekonomi yang beragam. Sementara itu, angka perceraian yang demikian juga berkaitan dengan kebiasaan melakukan pernikahan dalam kurun usia relatif muda.

Dalam melihat fenomena di atas, penulis menggunakan analisis sosio yuridis ${ }^{6}$ untuk mendeskripsikan fenomena pernikahan usia dini dan perceraian yang terjadi dalam masyarakat Jawa Timur yang memiliki basis tradisi budaya Islam yang kuat. ${ }^{7}$ Tujuannya untuk dapat menggambarkan dan membangun suatu pengetahuan yang bersumber dari analisis sosio yuridis tentang pernikahan usia dini dan perceraian di wilayah Jawa Timur.

\section{Kajian tentang Pernikahan Usia Dini dan Perceraian}

Dalam Undang-Undang Nomor 1 Tahun 1974, pasal 7 ayat (1) disebutkan bahwa pernikahan hanya diijinkan apabila pihak pria sudah mencapai usia 19 tahun dan pihak wanita mencapai usia 16 tahun. Namun demikian, di Jawa Timur banyak terjadi pernikahan dengan mempelai memiliki usia di bawah usia yang telah ditetapkan oleh Undang-Undang Perkawinan tersebut. Pernikahan ini seringkali disebut dengan pernikahan anak atau pernikahan usia dini.

Banyak faktor yang mendorong terjadinya pernikahan usia dini, di antaranya adalah masalah sosial dan ekonomi, serta rumitnya tradisi dan budaya yang hidup dalam suatu kelompok masyarakat. Stigma sosial budaya yang telah melegenda di

\footnotetext{
${ }^{6}$ Harry Hikmat, Metodologi Penelitian Sosial; Pendekatan dan Implikasi Pilihan Metode dan Teknik, (Jakarta: Dirjen Pendidikan Tinggi, Direktorat Pembinaan Penelitian dan Pengembangan Pada Masyarakat, 2000), 25-27.

${ }^{7}$ Lexy J. Moleong, Metode Penelitian Kualitatif, (Bandung: Remaja Roesdakarya, 1993), 12 - 14.
} 
masyarakat adalah sesuatu yang diyakini sebagai suatu realita budaya yang harus dilaksanakan dalam aspek pernikahan usia anak-anak. Beberapa budaya masyarakat Indonesia menganggap bahwa pernikahan setelah melewati masa pubertas, terutama di kalangan perempuan adalah sesuatu yang dianggap aib atau pantangan yang harus dihindari. Jika hal demikian diterjang, maka masyarakat menyebutnya dengan berbagai ungkapan yang bernada sindiran, misalnya sebagai perawan tua, tidak laku kawin, dan lain sebagainya. Penyebutan yang dianggap tidak pantas itu, dengan sendirinya harus dihindari oleh masyarakat, sehingga pernikahan anak mau tidak mau tetap berlangsung atau bahkan pada kalangan tertentu menjadi suatu keharusan.

Sementara itu, alasan motif ekonomi berdasarkan pada harapan tercapainya jaminan sosial dan finansial setelah menikah. Hal inilah yang menyebabkan banyak orang tua menyetujui pernikahan usia dini. Para orang tua sering dihadapkan pada persoalan yang dilematis. Di satu sisi, terdapat aspek harapan yang mungkin dipandang tidak berlebihan, sekiranya anakanaknya mendapat jaminan untuk masa depanya daripada mempertahankan usia anaknya yang tiap hari senantiasa bertambah tetapi masih belum mendapatkan calon yang bakal dijadikan jodohnya. Oleh karena itu, para orang tua tidak mempunyai banyak pilihan, kecuali harus menikahkan anaknya dengan orang lain meskipun masih dalam usia anak-anak. Alasan orang tua menyetujui pernikahan anak ini seringkali dilandasi perasaan was-was terhadap anaknya yang tidak mendapatkan jodoh dan bahkan timbul pula ketakutan akan terjadinya kehamilan di luar nikah akibat pergaulan bebas apabila tidak segera menikah.

Pernikahan yang demikian itu rentan sekali menimbulkan perceraian di kalangan masyarakat. Terjadinya perceraian antara pasangan keluarga merupakan jalan terakhir setelah proses panjang untuk membuat mereka tetap bertahan dalam keluarga telah mengalami jalan buntu. Perceraian merupakan suatu 
peristiwa yang tidak mungkin dapat dihindarkan. Pasangan dengan upaya maksimal untuk menyatukan keutuhan keluarganya tetapi timbul berbagai persoalan di antara keduanya yang tidak dapat disatukan bersama, maka peristiwa perceraian menjadi salah satu alternatif yang harus dilalui. Meskipun secara teoritis, ajaran agama Islam membuka kemungkinan pintu perceraian, namun perceraian adalah hal yang patut dihindarkan oleh setiap pasangan keluarga sehingga keharmonisan keluarga tetap terjaga. Perlu diakui bahwa dalam menjalani kehidupan yang demikian relatif panjang, tidak lepas akan timbulnya persoalan-persoalan, yang kadang-kadang persoalan itu dari yang sederhana, tingkat sedang dan bahkan sangat berat. Setiap pasangan keluarga dalam menghadapi persoalan keluarga tentu diharapkan dapat diselesaikan secara baik agar kehidupan dan keutuhan keluarga kembali normal.

Faktor-faktor terjadinya pasangan suami istri melangsungkan perceraian adalah sangat kompleks. Antara satu kasus dengan kasus lainya berbeda-beda. Namun demikian, secara garis besar penyebab timbulnya perceraian itu dapat diidentifikasi secara umum. Apabila perceraian itu terjadi, maka akan menimbulkan dampak begitu besar bagi pasangan suami istri, terutama menyangkut aspek psikologis pasangan. Bagaimanapun, pasangan suami istri yang pernah hidup bersama dalam satu keluarga, tentu menyimpan banyak pengalaman hidup yang tidak mudah begitu saja hilang bersamaan dengan berpisahnya pasangan. Kesan positif maupun negatif yang berupa rasa traumatik pasangan masih tetap terbawa dalam kurun waktu relatif panjang, tetapi secara psikologis itu akan berangsur-angsur menghilang seiring dengan perjalanan waktu.

Dampak lebih lanjut selain bagi pasangan suami istri adalah apabila pasangan suami istri tersebut telah dikarunia anak-anak, maka dapat dipastikan bahwa keputusan perceraian akan membawa dampak bagi kehidupan anak-anak yang ditinggalkannya, baik dari aspek hukum yang menyangkut status 
anak, maupun aspek psikologi yang umumnya menimbulkan bekas tidak baik bagi anak-anak yang ditinggalkan. Jika pendidikan anak terganggu, maka dikhawatirkan menimbulkan dampak berkelanjutan yang lebih kompleks, sehingga diperlukan solusi edukatif terhadap anak anak yang baru ditinggalkan oleh orang tuanya yang melangsungkan perceraian. Belum lagi persoalan anak-anak yang berkaitan dengan masa depannya ketika tidak ada figur dalam keluarga yang dapat dijadikan contoh atau tempat berlindung dan belajar hidup.

\section{Faktor Tradisi dan Budaya Lokal dalam Pernikahan Usia Dini}

Tradisi budaya lokal dan sistem sosial yang memposisikan ayah sebagai kepala keluarga dengan bersikap dan bertindak yang terkesan otoriter, sampai sekarang masih dipertahankan oleh sebagian masyarakat kita, baik di daerah perkotaan maupun di daerah perdesaan yang kental dengan budaya patriakhi. Meski demikian, sisi baik dari peran orang tua yang tentunya harus dihormati dan dijunjung tinggi.

Dalam budaya ini, yang perlu dikritisi adalah sikap otoriter yang menimbulkan ketidakberdayaan anak-anak, termasuk hakhaknya yang tidak berfungsi. Hal ini demi terwujudnya kesamaan hak antara anak laki-laki dan anak perempuan, yang tumbuh berkembang menjadi remaja dengan keleluasaan atas hak-hak yang melekat pada dirinya. Jika pekerjaan sosial yang demikian dapat ditunaikan secara berkelanjutan, maka lambat laun hak-hak yang dimiliki oleh usia anak-anak dapat dihormati sebagaimana hak-hak yang terdapat para orang tua.

Wajib disyukuri juga bahwa budaya itu terjadi di daerahdaerah yang sebagian besar sudah mulai ditinggalkan karena pengaruh dari maraknya gerakan hak asasi manusia dan persamaan hak. Jika suatu perkawinan dipaksakan, sementara anak-anak tersebut masih belum menginjak dewasa, itu berarti para orang tua tidak memahami hak-hak yang melekat pada diri anak-anak. Pada masa usia anak-anak, hak-haknya tentu berbeda dengan usia dewasa. Jika suatu perkawinan berlangsung, maka 
hal itu sama dengan memberi beban tanggung jawab yang tidak proporsional terhadap anak-anak.

Peranan dan status kaum laki-laki yang dimitoskan sebagai hal superior menyimpan implikasi dalam keluarga yang cukup dominan dibandingkan dengan pihak perempuan dan posisi kaum perempuan yang demikian tidak banyak menguntungkan bagi dirinya. Pasangan mempelai usia anak-anak yang berstatus perempuan memiliki kapasitas yang terbatas untuk dapat menyuarakan pendapat, menegosiasikan keinginan, berhubungan seksual, memakai alat kontrasepsi, dan mengandung anak. Demikian pula dengan aspek domestik lainnya, senantiasa menjadikan posisi kaum perempuan tidak bebas dan secara psikologis dalam tekanan atau pengawasan kaum laki-laki. Dominasi pasangan seringkali menyebabkan rentan terhadap kekerasan yang terjadi dalam kehidupan rumah tangga. Kekerasan dalam rumah tangga tertinggi terjadi di India, terutama pada perempuan berusia 18 tahun $^{8}$.

Adapun faktor-faktor penyebab terjadinya pernikahan usia dini adalah:

1. Aspek pendidikan

Seharusnya anak-anak mempunyai peran yang besar dalam mengejar jenjang pendidikan lebih tinggi. Lebih produktif bagi kurun usia anak-anak untuk mengasah ilmu pengetahuan dan skill di berbagai bidang daripada menjadikan dirinya sebagai ibu rumah tangga. Jika hal itu dikerjakan dan akhirnya mempunyai pengalaman, maka kelak dijadikan modal dasar dalam hidup berumah tangga. Jika seorang anak putus sekolah pada usia wajib sekolah, kemudian mengisi waktu dengan bekerja, maka selain hal itu merupakan bentuk pelanggaran karena mempekerjakan anak di bawah umur, juga tidak baik untuk pertumbuhan otak anak-anak itu sendiri. Dengan pendidikan yang cukup disertai skill tertentu, maka

8 IHEU., UN Publishes IHEU Statement: Child Marriage Is cChild Abuse. www.iheu.org. diakses 29 April 2017. 
saat itu anak-anak sudah merasa cukup mandiri, merasa mampu untuk mengurusi diri sendiri dan dapat bertanggung jawab.

Di sini, terasa betul makna dari wajib belajar 9 tahun. Kewajiban yang telah memfasilitasi pendidikan dasar yang gratis, seharusnya dijadikan kesempatan untuk belajar dan menimba pengetahuan dan skill agar kelak menjadi orang berpengetahuan dan mempunyai skill. Jika diasumsikan bahwa anak-anak masuk sekolah pada usia 7 tahun, maka saat wajib belajar 9 tahun terlampaui, anak tersebut sudah berusia 16 tahun. Diharapkan dengan wajib belajar selama 9 tahun, maka hal itu mempunyai dampak terhadap angka pernikahan usia dini menjadi sedikit atau berkurang dan selain wajib belajar itu membebaskan anak dari penyakit buta huruf atau buta aksara.

2. Aspek hubungan biologis

Ada beberapa kasus yang dijumpai di masyarakat, ketika pernikahan diajukan oleh orang tua setelah melihat perilaku anaknya yang diduga melampaui batas ajaran agama. Anakanak diduga telah melakukan hubungan biologis layaknya pasangan suami istri. Melihat kondisi seperti ini, orang tua anak perempuan cenderung segera menikahkan anaknya, karena menurut para orang tua anak gadis ini, sudah tidak perawan lagi, dan hal ini menjadi aib bagi keluarga, sehingga perlu segera dinikahkan dengan pasangannya. Bahkan ada beberapa kasus, yang justru anak gadis tersebut pada dasarnya tidak mencintai calon suaminya, tetapi karena terlanjur mengandung atau hamil, maka dengan sangat terpaksa mengajukan permohonan dispensasi kawin.

Ini semua tentu menjadi hal yang sangat dilematis, baik bagi anak gadis, orang tua bahkan hakim yang menyidangkan. Dengan kondisi seperti ini, jelas-jelas perkawinan yang akan dilaksanakan bukan lagi sebagaimana perkawinan yang diamanatkan undang-undang bahkan oleh agama. Karena sudah terbayang di hadapan mata, kelak rona perkawinan anak 
gadis ini di kemudian hari mengalami berbagai persoalan internal rumah tangga. Bagaimanapun perkawinan yang tidak didasarkan rasa kasih sayang akan rawan terjadi perceraian. Dan jika hal itu terjadi, mungkin kehidupan si istri akan dalam tekanan psikologis. Sementara itu, perkawinan yang dilaksanakan berdasarkan rasa cinta saja kemungkinan di kemudian hari bisa goyah, terjadi keretakan rumah tangga apalagi jika perkawinan tersebut didasarkan keterpaksaan, tentu dapat dibayangkan suasana kehidupan rumah tangga.

Adapun penyebab terjadinya pernikahan usia dini dari lingkungan luar adalah sebagai berikut:

1. Faktor pemahaman agama

Ada sebagian masyarakat kita yang memahami bahwa jika anak menjalin hubungan dengan lawan jenis, telah terjadi pelanggaran agama, dan sebagai orang tua wajib melindungi dan mencegahnya dengan segera menikahkan anak-anak tersebut. Ada satu kasus, dimana orang tua anak menyatakan bahwa jika anak menjalin hubungan dengan lawan jenis merupakan satu: "perzinaan". Oleh karena itu sebagai orang tua harus mencegah hal tersebut dengan segera menikahkan.

Saat majelis hakim menanyakan anak wanita yang belum berusia 16 tahun tersebut, anak tersebut pada dasarnya tidak keberatan jika menunggu sampai usia 16 tahun yang tinggal beberapa bulan lagi. Tapi orang tua yang tetap bersikukuh bahwa pernikahan harus segera dilaksanakan. Bahwa perbuatan anak yang saling sms dengan anak laki-laki adalah merupakan "zina", dan sebagai orang tua sangat takut dengan azab membiarkan anak tetap berzina.

2. Faktor ekonomi

Kita masih banyak menemukan kasus-kasus dimana orang tua terlilit hutang yang sudah tidak mampu membayar, sementara itu anak sewayang gadis menjadi jaminan sebagai atas hutang-hutang tersebut. Dan jika si orang tua yang terlilit hutang tadi mempunyai anak gadis, maka anak gadis tersebut 
akan diserahkan sebagai "alat pembayaran" kepada si piutang. Setelah anak tersebut dinikahi, maka lunaslah hutang-hutang yang melilit orang tua si anak. Kasus ini baru-baru ini mencuat terjadi di Maros (Sulawesi Selatan), dimana seorang kakek berusia 60 tahun menikah dengan anak berusia 12 tahun. Orang tua anak tersebut sudah cukup senang, karena selain hutanghutangnya bisa terbayarkan juga karena anaknya tersebut telah dibelikan handphone oleh sang suami yang sudah berusia lanjut. Sebuah kisah yang sangat ironis.

3. Faktor adat dan budaya

Di beberapa belahan daerah di Indonesia, masih terdapat beberapa pemahaman tentang arti perjodohan, dimana anak gadisnya sejak kecil telah dijodohkan orang tuanya. Sejak masih kanak-kanak, para orang tua akan mencari seseorang yang bakal dijodohkan dengan anaknya tersebut. Jadi ikatan perjodohan ini dilakukan bertahun-tahun yang kemungkinan dalam masa masa menunggu seperti itu, masing-masing orang tua saling penjajakan dan tentu untuk mempererat tali persaudaraan, dan akan segera dinikahkan sesaat setelah anak tersebut mengalami masa menstruasi. Padahal umumnya anakanak perempuan mulai menstruasi di usia 12 tahun. Maka dapat dipastikan anak tersebut akan dinikahkan pada usia 12 tahun, jauh di bawah batas usia minimum sebuah pernikahan yang diamanatkan oleh peraturan.

Dalam kehidupan rumah tangga yang terdiri atas pasangan suami istri yang masih dikategorikan pasangan muda atau anakanak, rentan terhadap perselisihan atau cekcok antara keduanya hanya karena mempersoalkan hal-hal yang tidak penting. Masalah yang sederhana saja tidak mudah diselesaikan apalagi masalah yang lebih besar. Kondisi yang demikian disebabkan oleh tingkat pendidikan dan pengetahuan yang relatif terbatas yang tidak memungkinkan untuk berfikir panjang. Terutama pihak anak-anak perempuan yang sering mendapatkan perlakuan atau menghadapi berbagai bentuk kekerasan dalam rumah tangga, maka mereka 
mempunyai kecenderungan bersikap pasif, diam dan tidak melakukan perlawanan. Dengan demikian, pernikahan usia ini rata-rata menimbulkan akibat buruk bagi mempelai pasangan, merekapun tidak mendapat pemenuhan rasa aman, baik di bidang sosial maupun finansial ${ }^{9}$.

Selain itu, pernikahan dengan pasangan yang terpaut jauh usianya dapat menimbulkan persoalan yang lebih serius, karena timbulnya gap (jarak) antara suami istri, baik dalam bidang psikologis, pengalaman dan hubungan seksual. Pola sikap, tindakan dan pemikiran yang tidak pernah ketemu karena disebabkan oleh perbedaan usia itu kerap kali menjadi alasan bagi pasangan yang menikah dan dapat menjadi pemicu kekerasan dalam rumah tangga. Pertengkaran yang tidak jarang berakhir dengan kekerasan dipicu oleh perbedaan usia yang jauh. Apalagi pasangan itu, di satu sisi masih tergolong anak-anak atau belum cukup umur, maka mudah menimbulkan persoalan psikis bagi pihak perempuan itu sendiri. Dengan demikian, pernikahan dengan perbedaan umur yang terlampau jauh mudah menimbulkan resiko keluarga, dan kesatuan rumah tangga menjadi tidak lengkap akibat perceraian, atau menjanda karena pasangan meninggal dunia.

Lebih jauh lagi, perbedaan usia pasangan yang terlampau jauh menyebabkan anak-anak hampir tidak mungkin meminta hubungan seks yang aman akibat dominasi pasangan laki-laki. Pernikahan usia muda juga menimbulkan faktor resiko yang cukup tinggi akan terjadinya gejala karsinoma serviks, yaitu penyakit kanker yang muncul pada leher rahim perempuan. Keterbatasan gerak sebagai istri dan kurangnya dukungan untuk mendapatkan pelayanan kesehatan karena terbentur kondisi ijin suami, keterbatasan ekonomi, akan berkontribusi terhadap meningkatnya angka morbiditas dan mortalitas pada remaja yang hamil10.

${ }^{9}$ ICRW. Ending Child Marriage. www.icrwindia.org. diakses 29 April 2017.

${ }^{10} \mathrm{lbid}$. 


\section{Undang-Undang Perlindungan Anak dan Tradisi Pernikahan Usia Dini}

Bagi negara Indonesia, kedudukan Konvensi Hak Anak (KHA) menjadi amat penting dalam konteks kehidupan berbangsa dan bernegara. Sebagai negara yang jumlah penduduknya terus bertambah dan itu berarti bertambahnya usia yang dikategorikan sebagai usia anak-anak, perlu mendapatkan perlindungan secara normatif. Sejak tahun 1990 ketika pemerintahan Indonesia di bawah kepemimpinan Orde Baru, telah membuat terobosan hukum yang berkaitan dengan kehadiran konvensi tersebut. Keberadaan anak-anak Indonesia telah memperoleh perlindungan dari negara dan masyarakat Internasional sejak status KHA diratifikasi melalui Keppres No.36 Tahun 1990, untuk selanjutnya disahkan sebagai Undang-Undang Perlindungan Anak (UU PA) No. 23 Tahun 2002. Pengesahan Undang-undang itu bertujuan untuk mewujudkan perlindungan dan kesejahteraan anak ${ }^{11}$. Bahwa dalam UUPA dinyatakan secara jelas bahwa Negara Kesatuan Republik Indonesia menjamin kesejahteraan tiap-tiap warga negaranya, termasuk perlindungan terhadap hak anak yang merupakan hak asasi manusia.

Salah satu prinsip dalam KHA yaitu "kepentingan yang terbaik bagi anak". Maksud dari prinsip itu adalah dalam semua tindakan yang berkaitan dengan anak yang dilakukan oleh pemerintah dan masyarakat. Dalam UUPA pasal 1 ayat 2 disebutkan bahwa "perlindungan anak" adalah segala kegiatan untuk menjamin dan melindungi anak dan hak-haknya agar dapat hidup, tumbuh, berkembang, dan berpartisipasi secara optimal sesuai dengan harkat dan martabat kemanusiaan, serta mendapat perlindungan dari kekerasan dan diskriminasi yang sering terjadi dalam kehidupan rumah tangga dengan memandang anak sebagai obyek $^{12}$.

I' Undang-Undang Perlindungan Anak (UU PA) No. 23 Tahun 2002

$12 \mathrm{lbid}$ 
Dalam deklarasi hak asasi manusia juga dikatakan bahwa pernikahan harus dilakukan atas persetujuan penuh kedua pasangan. Namun kenyataan yang dihadapi dalam pernikahan usia dini ini, persetujuan menikah seringkali merupakan akumulasi dari paksaan atau tekanan orangtua/wali anak, sehingga anak setuju untuk menikah seringkali merupakan bentuk ketaatan atau sikap berbakti dan hormat pada orang tua. Di sisi lain, para orang tua beranggapan menikahkan anak mereka berarti suatu bentuk perlindungan terhadap sang anak. Namun hal ini justru menyebabkan hilangnya kesempatan anak untuk berkembang, tumbuh sehat, dan kehilangan kebebasan dalam memilih $^{13}$. Pernyataan senada juga dikeluarkan oleh International Humanist and Ethical Union, bahwa pernikahan anak merupakan bentuk perlakuan salah pada anak (child abuse)14. Dalam hal ini, mengingat berbagai konsekwensi yang dihadapi anak terkait dengan maraknya pernikahan usia dini sebagaimana telah dibahas, maka pernikahan anak tentunya menyebabkan tidak terpenuhinya prinsip "yang terbaik untuk anak", sehingga hal ini merupakan pelanggaran terhadap hak asasi anak.

Dalam UUPA dapat diketahui betapa besar perhatian negara terhadap keberlangsungan hidup anak-anak dalam mengsisi kehidupan di masa depan sehingga perlu mendapatkan perlindungan secara normatif-yuridis. Bahkan dalam pasal 77-90 tersebut mempunyai tujuan untuk menghindarkan resiko-resiko, baik secara medis maupun non medis terhadap tradisi pernikahan di bawah umur atau usia dini. Bagaimanapun resiko-resiko yang ditanggung oleh pasangan usia dini dapat menimbulkan kematian dan itu artinya komplikasi psiko-sosial akibat pernikahan dan kehamilan di usia dini tidak dapat ditoleransi oleh siapapun. Bahkan komplikasi psiko-sosial akibat pernikahan dan kehamilan di usia dini didukung oleh suatu penelitian yang menunjukkan

\footnotetext{
13 Soetjiningsih, Tumbuh Kembang Anak, (Jakarta: Balai Penerbit FKUI, 2006), 22.

${ }^{14} \mathrm{WHO}$. Implementation og general assembly resolution 60/25I of march 2006 entitled "human rights council". www. unitednations.org., diakses 29 April 2017.
} 
bahwa dampak negatif sosial jangka panjang yang tak terhindarkan. Ibu yang mengandung di usia dini akan mengalami trauma berkepanjangan, selain juga mengalami krisis kepercayaan diri. Anak juga secara psikologis belum siap untuk bertanggung jawab dan berperan sebagai istri, patner seks, menjadi seorang ibu, sehingga jelas bahwa pernikahan anak menyebabkan imbas negatif terhadap kesejahteraan psikologis serta perkembangan kepribadian mereka15.

Ketika usia anak-anak masih dalam proses perkembangan fisik atau mengalami masa pertumbuhan, tetapi di sisi lain, anakanak itu mengalami proses kehamilan atau sedang mengandung, maka terjadi persaingan nutrisi antara sang ibu yang hamil dengan janin yang dikandungnya. Kondisi yang demikian, dapat mengakibatkan berat badan ibu hamil seringkali sulit naik, bakhan kemungkinan disertai dengan anemia karena defisiensi nutrisi, yang akhirnya berisiko melahirkan bayi dengan berat lahir rendah. Didapatkan bahwa sekitar $14 \%$ bayi yang lahir dari ibu berusia remaja di bawah 17 tahun adalah kelahiran yang prematur. Anatomi bagian panggul perempuan yang masih dalam pertumbuhan berisiko untuk terjadinya persalinan lama sehingga meningkatkan angka kematian bayi dan kematian neonatus ${ }^{16}$.

\section{Analisis Sosio-Yuridis terhadap Fenomena Perceraian di Jawa Timur}

Sedangkan persoalan perceraian dijelaskan dalam UndangUndang Nomor 1 Tahun 1974 pasal 40 ayat (1) memuat ketentuan bahwa gugatan perceraian diajukan kepada pengadilan. Yang dimaksud dengan lembaga pengadilan disini ialah Pengadilan Agama, bagi mereka pasangan suami istri yang beragama Islam, dan Pengadilan Umum (Pengadilan Negeri) adalah bagi lainnya sebagaimana ditentukan oleh pasal 63 ayat (1) dan (2). Dalam pasal 39 (2) menegaskan bahwa untuk melakukan perceraian harus ada

${ }^{15}$ Soetjiningsih, Tumbuh Kembang Anak...,21 I-22.

16 lbid. 
cukup alasan dan alasan itu disertai dengan cukup bukti karena menjadi faktor-faktor mengapa keputusan tentang perceraian itu diperbolehkan. Misalnya, bahwa antara pihak suami istri itu tidak akan dapat hidup rukun sebagai suami istri dalam suatu rumah tangga yang beerlangsung bersama selama pernikahan. Sedangkan tata cara perceraian di depan sidang pengadilan itu, dan tata cara mengajukan gugatan kepada pengadilan itu, menurut pasal 39 ayat (3) dan pasal 40 ayat (2) diatur dalam peraturan perundangundang tersendiri.

Mengenai peraturan pelaksana dari undang-undang tersebut dimuat dalam Peraturan Pemerintah Nomor 9 Tahun 1975 tentang Perceraian. Dalam Pasal 14 s.d. 18 dan pasal 20 s.d. 36 Peraturan Pemerintah tersebut menjelaskan bahwa alasan-alasan yang dapat dijadikan dasar untuk melakukan perceraian menurut penjelasan pasal 39 ayat (2) Undang-Undang nomor 1 tahun 1974 dan diperkuat dengan pasal 19 Peraturan Pemerintah Nomor 9 tahun 1975 tersebut adalah:

1. Salah satu pihak berbuat zina atau menjadi pemabuk, pemadat, penjudi dan lain sebagainya yang sukar ditentukan;

2. Salah satu pihak meninggalkan yang lain selama dua tahun berturut-turut tanpa alasan yang sah atau karena hal lain diluar kemampuannya;

3. Salah satu pihak mendapat hukuman penjara selama 5 tahun atau hukuman yang lebih berat setelah perkawinan berlangsung;

4. Salah satu pihak mendapat cacat badan atau penyakit yang mengakibatkan tidak dapat menjalankan kewajibannya sebagai suami istri;

5. Salah satu pihak melakukan kekejaman atau penganiayaan berat yang membahayakan terhadap pihak lain; 
6. Antara suami istri terlibat pertengkaran terus menerus dan tidak ada harapan akan hidup rukun dalam rumah tangga. ${ }^{17}$

Jika kita melihat angka perceraian yang terjadi di Provinsi Jawa Timur pada 2013, sebanyak kasus perceraian 74.777 kejadian, maka angka itu jika dibandingkan dengan angka perceraian pada tahun 2014, terjadi kenaikan kasus perceraian dari tahun 3013 ke tahun 2014, yaitu sebesar 6.850 kasus perceraian. Angka perceraian yang terjadi pada tahun sebanyak 74.777 kasus juga masih dikategorikan tinggi dan apabila dibandingkan dengan kasus perceraian pada tahun 2012, maka angka perceraian dari tahun 2012 ke tahun 2013 sebanyak 57.352 kasus perceraian, dimana pada tahun 2012, yang hanya 27.425 kasus perceraian. Begitu juga ketika melihat angka perceraian yang terjadi pada tahun 2011 yaitu sebanyak 25.907 kasus perceraian, maka kasus perceraian dari tahun 2011 ke tahun 2012 mengalami peningkatan sebanyak 1.618 kasus perceraian.

Dari data perceraian ini, dapat ditarik suatu kesimpulan bahwa angka kasus perceraian yang terjadi di Jawa Timur dari tahun ke tahun berikutnya selalu mengalami peningkatan dengan prosentase yang berbeda. Meski demikian, kasus itu tetap dalam kenaikan yang tinggi. Maraknya kasus perceraian yang melanda kawasan Jawa Timur adalah suatu realita sosial yang harus disadari oleh semua pihak, terutama setiap calon pasangan keluarga atau pasangan yang sedang hidup berumah tangga. Bahwa dampak perceraian jelas tidak banyak menguntungkan pasangan itu sendiri dan pihak-pihak yang terlibat dalam keluarga pasangan. Yang paling terkena dampak dari peristiwa itu adalah anak-anak yang dihasilkan dari pasangan itu yang usianya masih belum cukup umur, terutama menyangkut masa depan mereka kelak.

17 "Peraturan Pemerintah Republik Indonesia tentang Pelaksanaan Undang-undang Nomor I Tahun 1974 tentang Perkawinan" dalam Undang-undang Perkawinan di Indonesia, (Surabaya: Arkola, t.t.), 48. 
Dari data tersebut di atas, sesungguhnya angka perceraian yang terjadi di wilayah Jawa Timur cukup tinggi dibadingkan dengan daerah Provinsi lainnya di wilayah Indonesia. Sebagaimana data yang disebutkan oleh pihak Badan Peradilan Agama (Badilag) Mahkamah Agung bahwa sejak empat tahun terakhir angka perceraian di Jawa Timur tertinggi secara nasional, dimana predikat tertinggi sebelumnya dipegang oleh kota Bandung, yang disebut sebagai kota Kembang. Padahal sebelumnya, pada tahun 2010 angka perceraian sempat dipegang Kota Bandung dengan angka mencapai 84.084 perceraian. Ketika perceraian di Kota Bandung mencapai angka begitu spektakuler, maka wilayah Kota Surabaya menduduki posisi runner up di bawah Kota Bandung dengan kasus perceraian mencapai 68.092.

Adapun secara detail dapat diklasifikasikan terjadinya pertengkaran terus menerus antara pasangan suami istri sehingga akhirnya menimbulkan peristiwa perceraian, yang diantaranya adalah pertama, yaitu terjadinya kegagalan dalam aspek berkomunikasi antara pihak suami istri dalam kehidupan rumah tangga. Kemungkinan tidak adanya kecocokan akibat kegagalan berkomunikasi antara suami dan istri sering menjadi pemicu pintu perceraian. Dampak dari kurangnya komunikasi antara pasangan suami istri ini membuat kurangnya rasa saling mengerti dan mengendurnya rasa saling perhatian dan biasanya terabaikannya saling kasih sayang sehingga faktor yang demikian ini membuat sering terjadinya pertengkaran pasangan itu. Apabila kondisi seperti ini dibiarkan secara terus menerus, maka lambat laun terputus hubungan yang saling menghargai dan menyayangi satu sama lainnya, dan di akhir penghujung terjadi peristiwa perceraian. Faktor komunikasi antara pasangan menjadi penentu bagi keharmonisan rumah tangga sehingga terbina baik hubungan yang bersifat saling pengertian itu dan jika kedua pihak tidak mau atau gagal berkomunikasi, yang terjadi adalah perceraian.

Faktor yang kedua yang menyebabkan perceraian adalah ketidaksetiaan pasangan dalam membangun kehidupan rumah 
tangga. Ketidaksetiaan adalah faktor dasar dari semua keretakan kehidupan rumah tangga, karena di antara pasangan itu tidak ada saling percaya dan memang tidak ada alasan yang menjadikan mereka untuk saling percaya, sehingga melahirkan kecurigaan, prasangka buruk dan bahkan tuduhan-tuduhan yang menjurus ke arah pertengkaran. Karena itu, faktor kesetiaan menjadi fondasi bagi membangun kehidupan rumah tangga yang berkelanjutan dan hidup dalam kondisi harmonis. Penyebab ketidaksetiaan ini sangat beragam dan setiap pasangan tentu memiliki kasus tersendiri mengapa faktor ini terjadi dalam rumah tangganya. Tetapi umumnya faktor ketidaksetiaan yang akhirnya berujung dengan perceraian adalah salah satu pasangan telah melakukan perselingkuhan dengan pihak lain.

Faktor ketiga adalah terjadinya tindak kekerasan dalam rumah tangga yang dipicu oleh beberapa faktor, baik yang prinsip maupun yang tidak. Bisa jadi faktor itu prinsip dipandang oleh suami tetapi oleh sang istri tidak menjadi hal yang prinsip, begitu juga sebaliknya, hal itu prinsip bagi sang istri tetapi bagi suami dianggap hal biasa. Perbedaan pandangan dan sikap yang demikian dapat menimbulkan ketidakcocokan dan tidak jarang menimbulkan kekerasan dalam rumah tangga (KDRT). Masingmasing pasangan tidak lagi mencapai titik temu dalam sikap dan pandangannya karena sifat ego dari pasangan ini tidak ada yang saling menyadari dan saling menang sendiri. Tidak sedikit persoalan yang menimpa pasangan menjadi pemicu ketidakharmonisan dalam rumah tangga sehingga pasangan itu berasumsi bahwa lebih baik memilih menyelamatkan kehidupannya dengan langkah bercerai karena sering mendapat penganiayaan, baik secara fisik maupun verbal.

Faktor keempat adalah masalah ekonomi yang menimpa kehidupan rumah tangga. Tidak sedikit faktor kemiskinan dijadikan sebagai alasan untuk perceraian, dimana umumnya pihak istri yang sering mengajukan untuk bercerai dengan suaminya disebabkan tidak terpenuhinya kebutuhan ekonomi 
sehari-harinya. Apalagi jika pasangan tersebut salah satunya tidak mempunyai penghasilan yang tetap dan akhirnya pendapatan rumah tangganya kurang atau tidak mencukupi kebutuhan hidup sehari-hari, maka pintu perceraian terbuka apabila di antara mereka tidak saling menyadari hal tersebut. Karena faktor ekonomi menjadi penting dalam membangun rumah tangga, maka sepatutnya calon pasangan yang akan membangun hidup bersama dalam rumah tangga, saling melakukan penjajakan antara mereka untuk akhirnya mencapai kata sepakat sehingga ketika hidup bersama tidak lagi menjadi problem rumah tangganya. Dengan menganggap sang suami tidak mampu memenuhi kebutuhan hidup keluarga, akhirnya pihak istri meninggalkan pasangannya dengan cara menempuh pintu perceraian.

Faktor kelima menyangkut persoalan pernikahan yang berlangsung dalam usia dini atau dinikahkan dalam usia masih anak-anak yang kerapkali dijumpai dalam kehidupan masyarakat kita. Tidak jarang, para orang tua menikahkan anak-anak yang masih belum mencapai umur yang menjadi syarat suatu pernikahan tetapi kerena berbagai alasan-alasan yang dianggap lebih prinsip akhirnya pihak orang tua memaksa untuk menikahkan anaknya yang dikategorikan masih anak-anak itu. Pernikahan usia dini dapat menimbulkan berbagai persoalan yang datangnya ketika kehidupan bersama dalam rumah sedang dimulai. Biasanya tidak ada persoalan permulaan berumah tangga tetapi kemudian di pertengahan jalan muncul berbagai perosalan. Umumnya tidak mendapatkan penyelesaian yang baik dari pasangan suami istri. Memilih menikah yang belum cukup umur membuat pasangan muda tersebut belum siap menghadapi berbagai kesulitan dalam kehidupan berumah tangga, sehingga seringkali keputusan yang dibuat oleh pasangan yang masih anakanak adalah bercerai saat menghadapi banyak tekanan hidup.

Faktor keenam adalah aspek perubahan budaya yang terjadi secara evolutif dalam kehidupan masyarakat, dimana perubahan itu berdampak pada sikap, tindakan dan kebiasaan-kebiasaan 
masyarakat. Longgarnya tata aturan terhadap tata pergaulan anakanak pada era sekarang membuat persepsi mereka tentang hal-hal yang dianggap sakral menjadi tidak lagi sakral, nilai-nilai sosial budaya yang sebelumnya dijunjung tinggi dan dihormati menjadi berubah dan tidak lagi dihormati. Sebagaimana peristiwa perceraian adalah sesuatu yang tabu, yang mana setiap pasangan hidup akan menjauhkan diri dari perkara tersebut, tetapi dalam era sekarang menjadi tidak lagi hal yang tabu untuk dihindari. Justru sebaliknya, perceraian menjadi kecenderungan dan gaya hidup banyak pasangan. ${ }^{18}$ Melakukan pernikahan dengan berbagai upacara yang dihormati kesakralannya dan perkara perceraian yang umumnya dihindari oleh setiap pasangan, pada era sekarang adalah sesuatu yang biasa terjadi.

\section{Penutup}

Faktor-faktor yang mendorong maraknya pernikahan anak adalah pertama, masalah sosial dan ekonomi. Kedua, rumitnya tradisi dan budaya yang hidup dalam suatu kelompok masyarakat. Ketiga, aspek pendidikan. Keempat, aspek hubungan biologis. Kelima, faktor pemahaman agama. Keenam, faktor ekonomi orang tua. Ketujuh, faktor adat dan budaya. Stigma sosial budaya yang telah melegenda di masyarakat adalah sesuatu yang diyakini sebagai suatu realita budaya yang harus dilaksanakan dalam aspek pernikahan usia anak-anak. Masyarakat masih menganggap bahwa pernikahan setelah melewati masa pubertas, terutama di kalangan perempuan adalah sesuatu yang dianggap aib atau pantangan yang harus dihindari.

Adapun faktor-faktor penyebab pasangan suami istri melangsungkan perceraian adalah pertama, terjadinya kegagalan dalam aspek berkomunikasi antara pihak suami istri dalam kehidupan rumah tangga. Kedua, ketidaksetiaan pasangan dalam membangun kehidupan rumah tangga. Ketiga, terjadinya tindak

18Penyebab Perceraian https://id-id.facebook.com/notes/keluarga-sakinah-mawadah-warohmahamanah-smwa/penyebab-perceraian/I0150131 I30016562 
kekerasan dalam rumah tangga yang dipicu oleh beberapa faktor, baik yang prinsip maupun yang tidak. Keempat, masalah ekonomi yang menimpa kehidupan rumah tangga. Kelima, pernikahan yang berlangsung dalam usia dini atau dinikahkan dalam usia masih anak-anak. Keenam, aspek perubahan budaya yang terjadi secara evolutif dalam kehidupan masyarakat, dimana perubahan itu berdampak pada sikap, tindakan dan kebiasaan-kebiasaan masyarakat.

\section{Daftar Pustaka}

Hakim, Rahmat. Hukum Perkawinan Islam. Bandung: Pustaka Setia, 2000.

Hikmat, Harry. "Metodologi Penelitian Sosial; Pendekatan dan Implikasi Pilihan Metode dan Teknik", Jakarta: Dirjen Pendidikan Tinggi, Direktorat Pembinaan Penelitian dan Pengembangan Pada Masyarakat, 2000.

Moleong, Lexy J. Metode Penelitian Kualitatif. Bandung: Remaja Roesdakarya, 1993.

Peraturan Pemerintah Republik Indonesia tentang Pelaksanaan Undang-undang Nomor 1 Tahun 1974 tentang Perkawinan dalam "Undang-undang Perkawinan di Indonesia". Surabaya: Arkola, t.t.

Soemiyati. Hukum Perkawinan Islam dan Undang-undang Perkawinan (Undang-Undang No.1, Tahun 1974, Tentang Perkawinan). Yogyakarta: Liberty, 1982.

Soetjiningsih. Tumbuh Kembang Anak. Jakarta: Balai Penerbit FKUI, 2006.

Undang-Undang Perlindungan Anak (UU PA) No. 23 Tahun 2002

D., Nur Ulfainyy. “Angka Perceraian di Jawa Timur Capai 80.000 Per Tahun", dalam http://surabayanews.co.id/2015/08/21/33114/angkaperceraian-di-jawa-timur-capai-80-000-per-tahun.html, diakses 15 Agustus 2017. 
http://Jatimprov.Go.Id/Read/Berita-Pengumuman/Tekan-AngkaPerceraian-Kemenag-Jatim-Setuju-Wacana-Kursus-PraNikah, diakses tanggal 15 Agustus 2017.

ICRW. Ending Child Marriage. www.icrwindia.org. diakses 29 April 2017.

IHEU., UN Publishes IHEU Statement: Child Marriage Is cChild Abuse. www.iheu.org. diakses 29 April 2017.

Penyebab Perceraian https://id-id.facebook.com/notes/keluargasakinah-mawadah-warohmah-amanah-smwa/penyebabperceraian/10150131130016562

WHO. Implementation og general assembly resolution 60/251 of march 2006 entitled "human rights council". www.unitednations.org, diakses 29 April 2017. 